Jennifer Bowen and John J. Riemer, "An Interview with Jennifer Bowen," Cataloging \& Classification Quarterly 59, no. 4 (2021), https://doi.org/10.1080/01639374.2021.1898509

\title{
An Interview with Jennifer Bowen
}

\author{
Jennifer Bowen \& John J Riemer
}

\begin{abstract}
How Jennifer Bowen's career began and the path it took, from music cataloging to administration, is traced. Her personal involvement in and responses to a great number of the major issues and challenges that arose in the cataloging world is covered. These include Multiple Versions, Functional Requirements for Bibliographic Records (FRBR), the eXtensible Catalog project, leading international efforts to develop a successor to AACR2, the emergence of the Program for Cooperative Cataloging (PCC), the ongoing value of descriptive cataloging work, the future of MARC and linked data, new roles metadata professionals need to take on, changes at ALA to support these roles, and the vision, leadership, and skills needed in metadata work. Her current day perspectives on these significant events is provided.
\end{abstract}

\section{Keywords}

Music catalogers, administrators, cataloging codes, online catalogs, Resource Description \& Access, Functional Requirements for Bibliographic Records, professional association work, cataloger roles, change management 
John Riemer (JR): You have a background in music, what attracted you to being a librarian?

Jennifer Bowen (JB): A lot of credit for that goes to my older sister, Ruth Haldeman, who spent her career as a reference librarian in a public library. I used to hang out at work with her sometimes when I was in high school at what was then Ann Arbor Public Library, so I had a pretty good sense of what her work was like. As an undergraduate, I majored in music - I was actually a music history major - but I had no idea what I was going to do career-wise. Ruth just sort of suggested, "Well, you could be a music librarian." I didn't even know that that was a possible career! Then I started to seek out the librarian who was the music specialist at my undergraduate institution and found out that, oh, that is a thing you can do. That was how I got interested in being a music librarian. I am very fortunate that I was introduced to librarianship as a career early on, while I was still an undergraduate. I went to library school right after I graduated, when I was only 21 . I was probably the youngest person in most of my classes, as most of my classmates had already worked in libraries before starting library school.

JR: Your first professional position was in the public library cataloging department. How did that shape your future career, in cataloging?

JB: My first position was at a large city public library, with a really amazing music collection. It was a fascinating place to work, but it was a very different environment from what I had experienced before. It was a fully unionized environment (while I was there I was a member of the United Auto Workers, Librarians Local!). I was definitely not prepared for that. I learned a lot about how to work in a union shop: being careful to not inadvertently ask someone to do something outside of their contract (like 
searching the authority file), and taking my breaks every day so that the union steward wouldn't get on my case ("use them or we might lose them", he always said!). I came away from that experience understanding how important unions can be to make sure that staff are treated fairly, but I was also frustrated by how rigid the workplace was. I was relieved to find that at my current institution most staff in the library is not unionized, and fortunately my experience is that my institution still treats staff fairly.

JR: In that public library setting, wasn't it such that most things had copy that you could get from a vendor, whereas in an academic library there is some original cataloging challenge?

JB: There was quite a bit of original cataloging and it was because of the size of the library and the size of the music cataloging backlog that I inherited. Someone had gone through the music backlog before I arrived and had of course pulled out all the stuff with good copy and what was left was the challenging backlog. So, it was a good experience for me to learn the ropes in performing both original and copy cataloging. And of course, I was also the only music cataloger there, and nobody else knew much about music cataloging. I learned early on the importance of professional associations. I started getting involved with the Music Library Association at that point, and also the Music OCLC Users Group, so that I would have colleagues that I could talk to and could ask questions of. If you're the music person, you've gotta do that especially if you're the only one at your institution.

JR: Since that time you've held a variety of professional positions related to cataloging, which have all been at the University of Rochester.

JB: Yes, when I left my public library position, I went to the Eastman School of Music's Sibley Music Library as a music cataloger. At Sibley I was fortunate to be in an environment where there were other 
music catalogers. It's a large music library that was again a really great learning experience for me. That was also when I started getting involved not only with the Music Library Association, but also with ALA, when I became the Music Library Association representative to CC:DA [ALA's Cataloging Committee: Description and Access]. This was my first opportunity to move to a broader sphere outside of music cataloging, and also to get involved in standards development. As you said, since taking that first position as a music cataloger I have stayed at the University of Rochester and moved up from being a cataloger to become head of technical services at the Sibley Library. I was then ultimately recruited over to the UR's River Campus Libraries, first as head of cataloging, then as assistant dean and now associate dean. I have been fortunate to have found a path here so that I could move up from one position to another.

JR: So you were the Music Library Association rep to CC:DA, this was one of your first professional appointments. How did that come about?

JB: I followed in the footsteps of my boss at the time, Joan Swanekamp. Joan was the person who inspired me to take my initial position at Sibley and was my first supervisor there. She had been the MLA rep to CC:DA and needed to step down, and I was able to step into that position. Joan clued me in to all the political things I needed to watch out for. At that point CC:DA was (and still is) a complex committee and there were a lot of long-term icons of the cataloging world serving on the group, all with strong agendas. The process of proposing and discussing rule revisions for AACR2 was also onerous, and fortunately Joan got me started in the right direction. The big thing, the big issue that we were dealing with at that point was multiple versions. And I stepped right into the middle of that.

JR: So, that was the one burning issue? 
JB: Yes. Everyone was very concerned about how various editions and formats of the same work were showing up in online catalogs, and looking for a solution. One particular solution for multiple versions was being proposed that seemed to be quite labor intensive. It involved putting linking OCLC numbers into records that had some relationship to each other. The Music Library Association thought that was a really bad idea, so I ended up of standing up in my very first joint CC:DA/MARBI meeting and saying just that. It was kind of trial by fire to get involved in that early on. Of course multiple versions was a really important issue for music libraries because scores and sound recordings have such complex bibliographic families, with scores and recordings of the same composition published in multiple formats. There was a lot of interest in finding a solution, or at least to find a way to better understand what we were dealing with. The FRBR model, [the IFLA Functional Requirements for Bibliographic Records] was useful in trying to gain that understanding.

JR: So that is how you got involved in FRBR?

JB: Yes, there were a couple of joint CC:DA/MARBI task forces related to multiple versions and I was involved with that effort. Apparently my perspectives with music were well-received, and I was then invited to chair a task force of the Joint Steering Committee for the Revision of AACR. Brian Schottlaender invited me to be the chair of that task force, which was called the Format Variation Working Group. We were charged to look at the FRBR entity "expression" and to try to figure out how we could pull that concept out and make it more explicit within AACR2. That was an amazing opportunity because I was chairing an international group with representatives from all of the AACR constituent countries. There were three other members from the US (Matthew Beacom, Paul Weiss, and Joan Schuitema). We also had Chris Oliver and Pat Riva from Canada, three members from the UK, and 
one from Australia. That was the first virtual group that I'd ever been a part of. We had conference calls from Australia, North America, and the UK, which felt like a really big deal in the early 2000 's. Just trying to work across all of those countries was something that was very new to me. We ended up having a couple of in person meetings too, so we managed to have most of the members meet face to face, which made things a lot easier. We ultimately came up with recommendations that we submitted to the JSC. I hope that what we did was useful in the work that led up to RDA and influenced the ultimate decision to actually make the break from continuing to revise AACR to developing something totally new. My work on the Format Variation group then led to my being asked to succeed Matthew Beacom as the ALA Representative to the Joint Steering Committee. So again, it was sort of a case of my apparently doing well at one thing and getting invited to do the next thing. That was again a wonderful opportunity and, again, Brian Schottlaender was very instrumental in my getting that appointment.

JR: What were the biggest issues during your tenure on the JSC?

JB: It was really deciding whether we should keep working on something that we were tentatively calling AACR3, which would have been a clear revision of AACR2, or whether we should do something else. At one point we had Kathryn Deiss from ALA guide us in a facilitated discussion to help us decide what direction to take. It was at that particular meeting in Chicago where we decided that we were going to put AACR3 to bed, and we were going to start something totally new. We realized that tweaking AACR2 was not going to work anymore and that we needed to start fresh. That is where we came up with a name for the new standard: RDA, Resource Description and Access. I believe Barbara Tillett came up with it, and I remember being concerned that the name might be confused with RDF! And yeah, it was sort of a monumental moment to have been in the room when RDA was born! 
Once we decided to do that, we started having lots of roadblocks and difficulties that we had not anticipated. The Joint Steering Committee had certain constituencies that it reached out to through CC:DA (in the US), and formal structured relationships to many other organizations. But we also realized that there were other constituencies and other types of metadata that weren't being consulted at all, but that probably should have been. There was a lot of controversy about how other groups should be represented, and whether we should start looking at things like linked data, which was a new concept to most of us. There were some constituencies that thought we were doing way too little and being much too conservative. But then we were hearing on the other side that we were doing way too much. For example, some members of "Big Heads" [ALCTS Technical Services Directors of Large Research Libraries Interest Group] recalled from their perspective as administrators how expensive it had been to transition from AACR to AACR2. They felt that the library world was not prepared to go through another change of that magnitude. They said we were doing way too much, and that libraries were not going to implement it, and we should stop work on RDA. We were hearing both ends of the spectrum-we should do more, or do less. It was quite an interesting time, I will say that!

JR: I remember the Dublin Core digital library project view that there should be some guidance for that work in RDA, and "Why doesn't RDA speak to that audience as well, and not just to the AACR2 crowd?"

JB: Yes, there were different factions, certainly, advising us about what we should do and how we should be doing it. Some of these constituencies were also questioning whether we even needed a new content standard: not because it would be too expensive to implement, but in their view of the future of cataloging we just wouldn't need such a thing. So there was a lot of disagreement, a lot of interesting conversation going on. As I look back on it, it was pretty contentious for a while, but necessary. Those conversations needed to happen. 
JR: So that places well in time the memorable conversation I had with you, I think it was in Ohio in January or February of 2006. You observed that catalogers were very vulnerable at the moment. Do you remember that?

JB: Yes, I do remember that and it was related to this. There was a lot of talk among administrators about, "Why are we spending all this money on cataloging?" and the conversations about RDA contributed to that conversation. I remember the contrast between the level of detail and niggly little stuff that we were talking about in RDA development, and contrasting that with conversations among administrators about the cost of developing a new standard. For example, there were conversations during RDA development about whether or not " $\mathrm{cm}$ " for centimeter was an abbreviation and should be followed by a period, or whether it's a symbol and should not be followed by a period. Coming from a cataloger's point of view this kind of thing might be significant, but it was hard to justify this kind of thing in the eyes of administrators who were asking "Why are we doing this?" So what I was getting at in that conversation with you was that we have to be able to justify what we're doing. I had a lot of concern, and I still do at times, that we need to get our heads out of the sand and make sure that what we're doing really makes sense.

JR: And perceptions at the time were "With full text online why do we even need summary level metadata?"

JB: Yes, and at that point, catalogers needed to be cautious about how we expressed ourselves because there was a real vulnerability there. 
JR: So you've served in leadership roles in a variety of professional organizations related to cataloging over the years, the Music Library Association, chair of the ALA Cataloging \& Classification Section (now Cataloging \& Metadata Management Section, CaMMS), chair of the Music OCLC Users Group, and have been involved in the Program for Cooperative Cataloging on and off since its founding. What is your perspective on the PCC and the impact the PCC has had on cataloging?

JB: The emergence of the PCC was a real turning point for cataloging, when a group of technical services administrators who wanted to make cataloging less labor intensive, less expensive, and more collaborative created a new organization to try to make that happen. I believe one of the motivators was a 1991 Library Journal article by Dorothy Gregor and Carol Mandel called "Cataloging Must Change." That article shook up a lot of people by basically saying, "Cataloging is way too expensive, we're spending much, much too much time on it, it is too inefficient, we can't afford this. It's got to change."

One of the initial task groups that led up to the PCC had the memorable name, "More, Better, Faster, Cheaper", and I believe that was the group that led the development of the PCC core record standard. In my opinion, the core record standard was one of the PCC's most influential activities because of the conversations that it generated among catalogers. With the new standard, the PCC tried to create a culture where the standard defined a base level of data that goes into a catalog record. If a record contained all of the "core" elements, it then met the standard. It was then up to catalogers to decide when to add more fields to a record. Thinking about cataloging in this way, as something that includes judgment on the part of a cataloger to decide how much metadata to put into a catalog record, was a big, big deal. Most catalogers had been taught to always create ultra-full catalog records, adding every conceivable data field for every item cataloged, so that other libraries wouldn't have to touch the record later when doing copy cataloging. The PCC core record standard basically asserted that it wasn't 
necessary to always do that, and that a cataloger could decide. It was hoped that this would lead to cataloging efficiencies, but this was a significant change to create a different mindset among catalogers, and there was a lot of resistance to it at the time.

JR: What limitations have you seen of the PCC?

JB: My first experience with the PCC was as part of a NACO funnel project, while I worked at the Sibley Music Library. We were one of a group of music libraries that joined together to create the NACO Music Funnel Project, which I believe was the first NACO funnel. The structure of the project meant that the Library of Congress could treat a whole group of smaller music libraries as a single entity, which greatly reduced administrative effort for them. It also made participating in NACO more feasible for small or specialized libraries. What we found, though, was that it was extremely difficult for us to reach the point where our submissions didn't need full review. The rigor with which our records were scrutinized was very high. We needed to have 100 perfect records before we could be considered independent and it took us years, years to get to that point. So the bar was very high to become an independent NACO participant, even within a funnel project.

When I moved out of the music library and started thinking about whether to bring NACO participation to the broader university, which is a smaller member of ARL, I always felt that it was too high of a bar for us to participate in the PCC as an independent member. It just never seemed feasible to me. It would be difficult for us to justify spending that amount of time and attention on authority records, and the burden would have landed on just a couple of catalogers. So I would love to see the PCC make some changes that would make NACO perhaps more manageable for more institutions. There really is a need, 
especially for libraries that are doing non-MARC cataloging and coming up with all kinds of entities that would be valuable to have in the authority file. I'd love to see more work done in that area.

JR: You served on the PCC Advisory Committee on Initiatives. What was that like?

JB: One of the things I really appreciated about that group was that I was invited to participate on it even though I was not at a PCC library, and there were other group members who also weren't at PCC libraries. There was a conscious effort to make sure that the group had a broader perspective. We made some recommendations about creating something like "NACO Lite," trying to lower the bar so that more libraries could participate in NACO. It was a little frustrating because we didn't see much immediate action as a result of our recommendations. While we didn't see a lot of results of that group effort right away (this was 2012-2013), I like to think that I was involved early on in some forward-thinking discussions about moving from authority control to broader identity management issues. Of course, we're finally seeing that move forward with work on researcher identities, ORCID, and things like that. So we're finally making some progress on those areas as a profession.

JR: You took a detour from your career in cataloging and metadata to work on an open source software development project, the eXtensible Catalog. How did that come about?

JB: This was an effort at my institution, the University of Rochester. Back in 2008, we were very interested in open source development and building systems. We were frustrated with our online public access catalog, looked at similar projects such as VuFind, and were inspired to develop something like that ourselves. I was excited to be able to bring my expertise in working with the FRBR model to this effort. My colleagues and I brainstormed a vision for a system that would use the FRBR model as the 
basis for displaying records for the public. We were inspired by other approaches to that, such as how VTLS created its FRBRized ILS. We attempted to do something similar, by pulling out the various fields in MARC records that belong to Work, Expression, Manifestation, and Item entities and then create separate records that would be linked in the system. Unfortunately, we learned that this model of linked records is probably not feasible. Our approach worked well for creating FRBRized displays and linked records in a static system, but once we started bringing in new records into the system, updating records and deleting records, and having to redo the links between the FRBR entities every time this happened, it was just not possible with the technology that we were using.

I hope that what we learned has been an impetus toward other approaches, such as linked data and BIBFRAME. I also hope that it has contributed to our understanding that while there is a lot of value in the MARC record - that we can reuse much of the metadata and align it with the various FRBR entities not everything in the MARC record can be reused in that way. We did the best we could with the existing metadata, and we learned what the limitations are. Another positive outcome of our work to develop the eXtensible Catalog was that we developed a metadata aggregation system, called the Metadata Services Toolkit, which is still available as open source software. It has been used in some communities to aggregate data from multiple repositories, such as by a consortium of governmental libraries in Spain and by the CARLI consortium in Illinois for their Voyager repositories. Various digital humanities projects have also used it to aggregate data from different repositories. I'm really proud that we were able to create software that was useful to a variety of communities. And overall, working on the eXtensible Caalog, we also learned certain things that worked and certain things that don't work, which is itself a valuable contribution to other projects. 
JR: I wanted to get your perspective on the linked data revolution. How did it to come to your attention?

JB: It came to my attention, first through RDA development and then later through my work on the eXtensible Catalog, as an alternative to the approach we were taking on that project. I learned most of what I know about linked data from Diane Hillmann, Jon Phipps, and Karen Coyle, about their vision for metadata based on vocabularies, ontologies, statements, and URIs rather than on metadata records. We started looking at ways that we might incorporate linked data into the eXtensible Catalog, such as incorporating URIs into MARC records and into the XC Schema that we were defining. The discussions that we had around the eXtensible Catalog ware around pulling statements out of bibliographic records - the phrase that Diane and Jon used was "shredding the record" - so you would end up with individual statements and not records. I started learning about this and it seemed to be where we ought to be going, especially given the problems we were having with managing linked records. Early on it was difficult to get interest in linked data because we didn't have a "killer app" as a front end that would help us to show people "this is what linked data can do for you." We needed another grant in order to investigate this. When we didn't get the funding, that was end of the development we did on the eXtensible Catalog. Since that time, other projects have been able to move linked data forward in ways that we had hoped to do. I do hope, though, that the work that we did both on RDA and the eXtensible Catalog helped to define how far we could actually implement the FRBR model in a linked data environment.

JR: So what promise does linked data hold in your mind? 
JB: I hope that it will allow library metadata to be reusable out of the library sphere. When I see how marginalized library metadata has become (especially MARC), how much time and care we took to create it, and how it isn't really usable in other environments, it makes you realize that we need to be looking at something totally different. And when I look at other databases that are out there, they're so much better than anything we ever could have created, and I think about, for example, the time and money that was spent adding analytics and contents notes for sound recordings. While it seemed like the right thing to do at the time, that ultimately has ended up to not be the way to go. It's very hard sometimes to give up on what we have always done and realize that others are doing this better and differently in a different sphere, but that's what happened.

JR: What are the liabilities with linked data and what are the big unknowns?

JB: I think the difficulty still is how it is going to be implemented. And, we're at the mercy of our system vendors to know how that's going to happen. One of the other liabilities that people talk about is that you don't have the provenance of the metadata so you don't know where it came from to assess if it's accurate, whereas in a MARC environment you know who created the metadata. The other unknown is how linked data will actually affect catalogers. We are sort of at the same place with BIBFRAME now that we were in for quite a while with Dublin Core. It is the new thing we need to learn, it's coming, but we don't know what to do with it yet. So it's kind of an awkward time, I would say, to learn and try to retain new skills until there's an opportunity to actually use them.

JR: As someone with administrative responsibilities that include cataloging and metadata, what do you think about? 
JB: One of the difficulties right now is that I don't see a lot of people in the profession that have expertise that crosses between traditional cataloging and metadata as well as expertise related to digital collections. We need people who have an understanding of both. Metadata professionals who are newer to the profession tend to be going toward digital metadata, as of course they should, and are learning coding and schema building and all of that. That's all good, but on the other hand, we have this huge corpus of MARC data and it needs to be managed, as well as the whole supply chain of metadata for things that libraries are purchasing in an acquisitions workflow. So there are two streams of things going on, and finding people who can bridge that gap can be difficult.

JR: What type of leadership have you consciously sought to provide to professionals in cataloging?

JB: There is a need to cultivate management and leadership skills among cataloging and metadata experts and soft skills in how to be a leader, as well as domain knowledge across that divide between traditional cataloging and metadata that I just mentioned. I know that not all cataloging and metadata professionals are interested in developing leadership skills, but there's a great need for them. It's been important to me to encourage colleagues to develop both types of skills. I really enjoyed the three years that I spent as chair of the ALCTS Leadership Development Committee, working with an awesome group of ALCTS members who wanted to develop their own leadership skills as well as develop programming and resources that would help others do so too. We need to continue to encourage this in our profession. Catalogers need skills in managing people, team building and coaching others. They also need the ability to see the big picture of a situation and to see things from a different point of view. One thing I've noticed is that some of my cataloging colleagues become advocates for cataloging and metadata along the lines of "Cataloging doesn't get the respect it deserves" or "We need to advocate for technical services, because otherwise we are not going to get funding, attention, staffing, etc." 
Sometimes I think that this kind of advocacy stance becomes an adversarial conversation, and there are other ways, more effective ways, for metadata and cataloging professions to collaborate with others. This again comes back to some skill sets that we need to encourage. It may mean that we have to compromise about standards or how we do things in order to consider a bigger picture.

JR: Do you have other advice for existing professionals?

JB: It's always to look at the big picture and to look beyond the needs of a single catalog department or even the needs of the cataloging/metadata profession. With some of the conversations going on in ALA right now, and with the three ALA divisions ALCTS, LITA, and LLAMA looking at forming one division, there's an acknowledgement that library professionals need to develop their skill sets across their careers, and this includes leadership skills. ALCTS has had five different sections and members have tended to find a home in a particular section without looking beyond it for ways to collaborate or to develop different ways to look at things. So, the advice I would give is to look for the big picture and expand their professional networks.

$J R$ : What are you passionate about or find inspiring?

JB: I have become more involved with collections in my role as associate dean so this takes us a little bit further afield from talking about cataloging. I've become more passionate about looking at our individual library collections as a collective collection: looking at issues related to what materials libraries are going to keep or not keep. How can we keep track of collections across a broader environment where there are a lot of collaborative projects going on, distributed repositories, all kinds of things? I find that I'm really passionate about ensuring that we maintain access to physical materials 
themselves and make sure that they are accessible when they're needed. Actually this still relates to cataloging and metadata, because the devil is always in the details. The difficulty is always in the cataloging and ensuring that we've got the right holdings information. In one of the projects I've been involved with, one of the obstacles has been how to deal with multi-volume sets; again, it's all about the metadata. Collaborative collection management projects are going to sink or swim based on whether we have infrastructure and metadata to allow us to keep track of who's retaining what, where is it, and how we can lend it back and forth. So that's my latest area of interest, and what I find ironic is that in order for things to work, it's still all about the metadata! [laughter]

JR: So, it's okay to be picky, if it's about the right things!

JB: Yes, the metadata has to be right. But it's still being picky in the context of a larger vision.

JR: What are your hopes and dreams for the library profession in the realm of metadata?

JB: I'm excited by seeing opportunities at my institution where staff with metadata expertise are becoming recognized for their skill sets outside the library, that they can provide expertise to other types of endeavors outside the library, such as curating research data and managing institutional administrative data. There are a lot of possibilities here that many of us in the profession have never been involved with before. It requires competencies with using and creating metadata schemas and vocabularies, of course, and it also requires the ability to collaborate with a researcher or administrator to understand their needs. It may involve doing something totally unfamiliar to demonstrate how metadata expertise can be useful to the project. There's a whole realm of capacity building and skill set building involved, such as being able to put yourself out there and describe what you can do. I'm hopeful 
that we can have the next generation of metadata librarians working in these realms as an expected part of their activities.

JR: What would you like to be remembered for?

JB: I think for being willing to be involved in things when we weren't sure if they were going to be a success, and for being willing to get to the point where we could say, "You know, this isn't working. We need to think about doing something else,"- that we learn from some of our mistakes and we move on. I hope that I've had a role in some of that moving on. I don't see myself as someone who stood up early on with a project and said, "We can't do that" but rather to give a project the benefit of the doubt and say, "Okay... we'll give it a try and we'll try to make it work". While in hindsight I can identify times when I wish I had expressed my concerns sooner, I still hope that I will be remembered for being willing to commit to working on something. I also hope I'll be remembered for having a role in building the capacity of metadata professionals to be prepared for the future. In my role as president-elect of ALCTS, and engaging with conversations about forming a new ALA division, I hope that whatever comes out of these efforts put the association and the various ALA divisions in a position to move forward with strength and sustainability. Again, I was elected during a transition period, so it fits a pattern in my career in that a lot of the things that I've been involved in have been transitional moments, where we've tried something and said "We're giving this one last shot,", and then move toward to "What are we going to do differently?" or "How are we going to prepare for the future?" So this latest challenge feels like another situation like that.

JR: Finally, what things keep you up at night? 
JB: That would be ruminating about the question, "Are we doing the right thing?" It's worrying about whether or not whatever it is we're working on is going to work, no matter whether it's something that we've been doing for ages, or something new and different that we're just starting. I wonder, is this going to work, or is it time to be doing something different? And if the latter, is this the right time to step up and express my concern? Even after learning lots of lessons from previous projects, I worry about this.

\section{Epilogue}

JR: Jennifer, it's actually been a year since I first interviewed you. What would you like to add to our previous conversation? What has been on your mind during the intervening time?

JB: Well, aside from COVID and various political events, the thing that has most occupied my thoughts has been my recent role as President of ALCTS as ALCTS transitioned to the new ALA division, Core: Leadership, Infrastructure, Futures. While I didn't end up being quite the last President of ALCTS, I at least have the distinction of saying that I was the last ALCTS President to serve a full year term before the transition!

During that last year leading ALCTS, I once again had those doubts about "are we doing the right thing?" in working with LITA and LLAMA to form Core, but at this point in my career I've become more confident in assessing when something just needs to happen based upon reviewing the situation. We listened to the advice of ALA division staff, who were in the best position to know what was needed. We looked at ALA's precarious financial state, looked at trends in ALA membership and trends in the profession, and it was clear that we needed to make a major change. I was also reassured that we were taking the right 
actions by working with the leaders of the other two divisions on the transition. I know that many former members of ALCTS and CaMMS are focused right now on finding their own niche within the new division, and that's understandable. However, I hope that they will also enjoy participating in other areas of Core's work and with a broader cohort of Core members, again, to broaden their networks. I'm looking forward to this too, and especially to a time when we can begin to see each other in person again. I've found that the relationships with others that we've build over time end up being even more meaningful than the actual things that we accomplished, especially as things change so quickly. That's more important to me in the long run than whether or not a specific effort ended up to be a success at a particular moment. 


\section{JENNIFER BOWEN}

Curriculum Vitae

\section{ADDRESS}

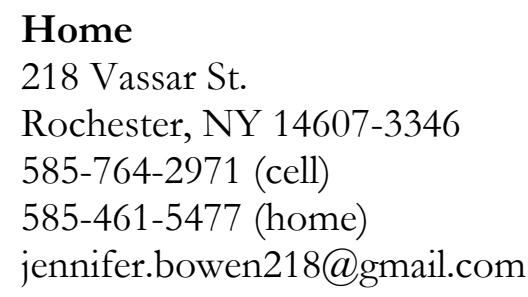

Home

218 Vassar St.

Rochester, NY 14607-3346

585-764-2971 (cell)

585-461-5477 (home)

jennifer.bowen218@gmail.com

Office

Box 270055

River Campus Libraries

University of Rochester

Rochester, NY, 14627-005

585-275-0004 (office)

jbowen@library.rochester.edu

\section{EDUCATION}

MA, Historical Musicology (1982), University of Michigan, Ann Arbor, MI AMLS, Library Science (1981), University of Michigan, Ann Arbor, MI

Bachelor of Music, Music History (1979) (Summa cum laude), Central Michigan University, Mt. Pleasant, MI

\section{PROFESSIONAL EXPERIENCE}

Associate Dean, Scholarly Resource Management 2016-

Assistant Dean, Scholarly Resource Management 2014-2016

Assistant Dean, Information Management Services 2009-2014

Chair, Board of Managers, eXtensible Catalog Organization, LLC 2011-2014

Co-Executive Director, eXtensible Catalog Organization, LLC 2010-2011

River Campus Libraries, University of Rochester, Rochester, NY

Director of Metadata Management 2007-2009

Co-Principal Investigator, eXtensible Catalog (XC) Project 2006-2010

River Campus Libraries, University of Rochester, Rochester, NY

Head of Cataloging, University of Rochester Libraries 2000-2007

River Campus Libraries, University of Rochester, Rochester, NY

Head of Technical Services, Sibley Music Library 2000-2007 
Eastman School of Music, University of Rochester, Rochester, NY

\section{Acting Co-Director}

2000

Head of Technical Services

1998-2000

Associate Head of Technical Services for Cataloging and Automation 1991-1998

Acting Head of Circulation

1993-1994

Catalog Librarian

1988-1991

Sibley Music Library, Eastman School of Music, University of Rochester, Rochester, NY

\section{Music Cataloger Specialist}

1985-1988

Detroit Public Library, Detroit, MI 


\section{SELECTED PROFESSIONAL DEVELOPMENT ACTIVITIES}

\section{Council on Library and Information Resources (CLIR)/EDUCAUSE}

Leading Change Institute, 2016

University of Rochester. Warner School of Education (with Ramerman Leadership Group). Leadership Coaching Certificate Program, 2014-15

Harvard University Graduate School of Education.

Library Leadership in a Digital Age, March 2014

\section{PUBLICATIONS}

“Thriving In and Out of 'Our Element.” Technicalities 38, no. 4 (July/August 2018) (Forthcoming)

“Zombies, Masquerades and Dead Horses: Finding Motivation in a 'Post Collections' World." Technicalities 37, no. 1 (January/February 2017): 1-7.

"Embracing Technical Services Values in a Changing Profession" Technicalities 35, no. 6

(November/December 2015: 9-12.

"Moving Library Metadata Toward Linked Data: Opportunities Provided by the eXtensible Catalog." Proceedings of the International Conference on Dublin Core and Metadata Applications, DC-2010: 44-59.

"Supporting the eXtensible Catalog through Metadata Design and Services". White paper published via the eXtensible Catalog Project website, January 8, 2009. http://hdl.handle.net/1802/6377

"Metadata to Support Next-Generation Library Resource Discovery: Lessons from The eXtensible Catalog, Phase 1." Information Technology and Libraries, 27 no. 2 (June 2008): 6-19.

"What's After AACR2? Addressing Questions about RDA: Resource Description and Access." ALCTS Newsletter Online, 16 no. 6 (December 2005).

"FRBR: Coming Soon to Your Library" Library Resources and Technical Services, 49 no. 3 (2005): 38-49. (Winner of the ALCTS "Best of LRTS" award for 2006)

Bowen, Jennifer, Judi Briden, Vicki Burns, David Lindahl, Brenda Reeb, Melinda Stowe, and Stanley Wilder. "Serial Failure." The Charleston Advisor, 5 no. 3 (Jan. 2004).

"Creating a Culture of Cooperation." Cataloging and Classification Quarterly 26, no. 3 (1998): 73-86; translated into Korean by Sook-hyeun Lee in Doseogwan 54 no. 1 (Spring 1999): 109-119.

\section{RESEARCH GRANTS}

\section{The Andrew W. Mellon Foundation} 2009-2011

Scholarly Communication Program: "eXtensible Catalog Bridge Grant"

$$
\$ 175,000
$$

Principal Investigators: Susan Gibbons, David Lindahl, Jennifer Bowen, and Nancy Fried Foster 


\section{The Andrew W. Mellon Foundation}

2007-2009

Scholarly Communication Program: "eXtensible Catalog Phase 2" $\$ 750,000$

Principal Investigators: Susan Gibbons, David Lindahl, Jennifer Bowen, and Nancy Fried Foster

\section{The Andrew W. Mellon Foundation} 2006-2007

Scholarly Communication Program: "eXtensible Catalog Phase 1" $\$ 280,000$

Principal Investigators: Ronald Dow, David Lindahl, Jennifer Bowen, and Nancy Fried Foster

\section{PRESENTATIONS}

Presentations on Linked Data and the eXtensible Catalog

- Northern Ohio Technical Services Librarians Fall meeting, Kent, OH, November 2013 (slides: http://preview.tinyurl.com/NOTSL2013)

- ALA Annual Conference, LITA Next Generation Catalog Interest Group, Anaheim, CA, June 2012

- $\quad$ ALA LITA/ALCTS Linked Data Preconference, Anaheim, CA, June 2012

- Cornell University Libraries, Ithaca, NY, May 2012

- Coalition for Networked Information, Spring Task Force Meeting, Baltimore, MD, April 2012 (video: www.cni.org/topics/information-access-retrieval/linked-data-for-libraries/)

- Code4lib Conference, Seattle, WA, February 2012

- ALA Midwinter Meeting: MARC Formats Interest Group, Dallas, TX, January 2012

- [With David Lindahl] Library of Congress, for U.S. RDA Test Coordinating Committee, March 2011

- International Conference on Dublin Core and Metadata Applications, Pittsburgh ,PA, October 2010 (slides: http://preview.tinyurl.com/DCMI2010)

- ALA Linked Data Preconference, Washington, DC, June 2010

- ALA Annual Conference: President's Grassroots Program, Chicago, IL, July 2009

General Presentations on the eXtensible Catalog

- ALA Annual Conference: ALCTS FRBR Interest Group; ALCTS Program, "Current Research on and Use of FRBR in Libraries", Anaheim, CA, June 2012

- ALA Midwinter Meeting: LITA Next Generation Catalog Interest Group, Dallas, TX, January 2012

- $\quad$ ASIS\&T 2011, New Orleans, LA, October 2011

- ALA Annual Conference, New Orleans, LA, June 2011: ALCTS Forum; Drupal Interest Group

- NISO “Future of the ILS: Part 2" Webinar, May 2011

- University of Wisconsin at Milwaukee School of Information, April 2011

- ACRL Annual Conference, Philadelphia, PA, March 2011 
- Canadian Library Association Conference and RDA Preconference, Edmonton, Alberta, June 2010

- CARLI/ERIAL webcast, May 2010

- NYLink Cataloging Workshop, Syracuse, NY, May 2010

- eXtensible Catalog Organization Spring Meeting, Charlotte, NC, May 2010

- ELUNA (Ex Libris Users Group), Ft. Worth, Texas, May 2010

- University of North Carolina at Charlotte Library, February 2010

- Code4lib 2010, Asheville, NC, February 2010

- ALA Midwinter Conference, Boston, MA, January 2010: FRBR Interest Group; Catalog Form and Function Interest Group; Metadata Interest Group; ALCTS/LITA Authority Control Interest Group

- LYRASIS Bibliographic Services Conference, Worcester, MA, November 2009 (keynote)

- New York Library Association Annual Conference, Niagara Falls, NY, October 2009

- Cornell University Libraries, Ithaca, NY, May 2009

- Central New York Library Council Workshop, Utica, NY, May 2009

- NISO “Data Movement and Management” Webinar, March 2009

- ALA Midwinter Conference. ALCTS President's Program, Boston, MA, January 2009

- ALA Annual Conference, "Future of Catalogs" program, Anaheim, CA, 2008

- [With David Lindahl] OCLC, Inc., Dublin, Ohio, June 2008

- ACRL Western NY/Ontario Spring Annual Symposium, Niagara Falls, NY, 2008

- CARLI (Consortium of Academic Libraries in Illinois) [annual meeting], Champaign, IL, October 2007

- [With David Lindahl] Library of Congress, Washington, DC, September 2007

- $\quad$ ALA Annual Conference, Washington, DC, July 2007

- Library and Archives Canada, Ottawa, CA, April 2007

- eXtensible Catalog Partner Meeting, Rochester, NY, February 2007

- Music Library Association Annual Conference, Pittsburgh, PA, February 2007

- [With Cynthia Carlton] Rochester Regional Library Council, Rochester, NY, December 2006

- [With David Lindahl] Coalition for Networked Information Fall Task Force, Washington, DC, November 2006

- [With David Lindahl] OCLC, Inc., Dublin, Ohio, June 2006

\section{Presentations on $R D A$ (Resource Description and Access)}

- Music Library Association, Pittsburgh, March 2007

- ALA Midwinter Conference: RDA Forum, Seattle, WA, January 2007

- Rochester Regional Library Council, Rochester, NY, November 2006

- Online Audiovisual Catalogers Conference, Phoenix, AZ, October 2006 (keynote speaker)

- American Association of Law Libraries, St. Louis, MO, July 2006

- ALA Annual Conference: RDA Forum, New Orleans, June 2006

- Cornell University, Ithaca, NY, May 2006

- ALA Midwinter Conference: Continuing Resources Cataloging Committee; Authority Control Interest Group; RDA Forum, San Antonio, TX, January 2006

- New York Library Association (Rudi Weiss Memorial Lecture), Buffalo, NY, October 2005

- ALA Annual Conference, Chicago, IL, June 2005

- ACRL 12 $2^{\text {th }}$ National Conference, Minneapolis, MN, April 2005

- $\quad$ ALA Midwinter Conference, Boston, MA, January 2005 


\section{General Presentations on FRBR (Functional Requirements for Bibliographic Records)}

- SUNY Library Association Annual Conference, Geneseo, NY, June 2006

- Buffalo State College, Buffalo, NY, November 2005

- New York Public Library, New York, NY, November 2005

- Rochester Regional Library Council, Rochester, NY, November 2004

- New York Library Association Annual Meeting, Rochester, NY, October 2004

- ALA Annual Conference. ALCTS Preconference "Back to the Future", Orlando, FL, June 2004

- American Association of Law Libraries Annual Conference, Boston, MA, July 2004

- Music Library Association Annual Conference, Alexandria, VA, February 2004

- Mid-Atlantic Voyager Users Group Meeting, Ithaca, NY, October 2002

Presentations on the Program for Cooperative Cataloging's Core Record Standard

- Rochester Regional Library Council, Rochester, NY, Summer 1999

- Michigan Library Association Fall Meeting, Lansing, November 1998 (keynote speaker)

- Music Library Association Annual Meeting, Boston, February 1998

\section{Other Presentations}

- Library of Congress Future of Bibliographic Control Task Force. Invited Speaker, Second Public Hearing, Chicago, May 2007

- [With David Lindahl] "Metadata that Supports Real User Needs" LITA Forum, San Jose, CA, October 2005

- "MODS, MARC, and Metadata Interoperability” ALA Annual Meeting, Chicago, IL, 2005

- [With Phil Ponella] "Endeavor's Voyager System; Music in the Next Generation of Library Systems." Music Library Association Annual Meeting, New Orleans, LA, 1997; also Music Library Association Western New York/Ontario Chapter Meeting, 1996

- "Trends in Descriptive Cataloging: Cooperation and Relationships" Music Library Association Annual Meeting, Seattle, WA, 1996

- [With Joan Swanekamp] "Sound Recordings Cataloging" Online Audiovisual Catalogers Annual Meeting, Rochester, New York, 1990

- "Multiple Versions for Scores And Sound Recordings: The Current Situation" Music Library Association Annual Meeting, Tucson, AZ, 1990

\section{PROFESSIONAL SERVICE}

American Library Association

Association for Library Collections and Technical Services (ALCTS)

Board of Directors: President elect, 2018- ; Director at Large, 2014-2015

Leadership Development Committee: Chair, 2015-2018

Cataloging and Classification Section

Executive Committee: Chair, 2003-2004; Member-at-Large, 1992-1993

Committee on Cataloging: Description and Access (CC:DA)

Joint Steering Committee Representative, 2004-2007

Relator Information Task Force, 2003-2004

Reproductions Guidelines Review Task Force: Consultant, 1993-1994

Multiple Versions Task Force: Chair, 1991-1992; Member, 1989-1991

Music Library Association Liaison, 1989-1992 
Eastern Academic Scholars' Trust (EAST)

Executive Committee: 2017-

Endeavor Information Systems, Inc.

Authority Control Task Force: 1998

OPAC Development Task Force: 1996

Joint Steering Committee for Revision of Anglo-American Cataloguing Rules (later, for Development of $\boldsymbol{R D A})$

American Library Association Representative, 2004-2007

Format Variation Working Group: Chair, 2001-2004

International Conference on the Principles and Future Development of AACR, 1997: Invited participant

Music Library Association

Bibliographic Control Committee

Working Group on Dublin Core Relator Element, 2000-2001: Chair, 1992-96; Member, 1989-92

Subcommittee on Descriptive Cataloging: Chair, 1988-1992; Member, 1987-1988

Working Group on Subject Access to Popular Music: 1987-1989

Music OCLC Users Group.

Chair , 1990-1992

NACO Music Project Advisory Committee, 1991-1992, 1997-1999

OCLC

Global Council/America’s Regional Council: Delegate, 2016-

Online Audiovisual Catalogers

Program Committee, 1990

Program for Cooperative Cataloging

Advisory Committee on Initiatives, 2011-2014

Policy Committee, 1997-2002

042 Working Group, 2000: Chair

Nominating Committee: Chair, 2000, Member, 1998

Executive Council, 1996-1997

Rochester Regional Library Committee

Regional CD-ROM Catalog Planning Committee, 1989-1991

Voyager Music Users Group

Founder and Coordinator, 1997-1999

AWARDS

\section{ALCTS (Association for Library Resources and Technical Services) Presidential Citation,} 2007

Awarded for work on behalf of ALA toward the development of $\mathrm{RDA}$ : Description and Access

"Best of LRTS" (Library Resources and Technical Services), 2006 
Awarded for the best paper of the year for "FRBR: Coming Soon to YOUR library"

Staff Recognition Award, University of Rochester River Campus Libraries, 2004

Adult Volunteer of the Year, YMCA of Greater Rochester, NY, Carlson MetroCenter Branch, 2000

\section{CURRENT PROFESSIONAL AFFILIATIONS}

American Library Association

Association of College and Research Libraries (ACRL)

Core: Leadership, Infrastructure, Futures (a division of ALA) 